\title{
Pengaruh Nilai Tukar dan Produk Domestik Bruto Dunia terhadap Volume Ekspor Indonesia
}

\author{
Manajemen Pemasaran \\ Eka Sudarusman \\ Sekolah Tinggi Ilmu Manajemen YKPN \\ Email: ekasud@yahoo.com
}

\begin{abstract}
ABSTRAK
Penelitian ini bertujuan untuk menguji pengaruh nilai tukar dan PDB dunia terhadap volume ekspor Indonesia untuk periode 1976-2018. Kami menggunakan nilai tukar antara Indonesia (IDR) dan Amerika Serikat (USD) dan PDB dunia yang semuanya diukur dengan harga konstan 2010. Peneliti menggunakan mekanisme koreksi kesalahan/Error Correction Mechanism (ECM), untuk menjawab pertanyaan penelitian. Hasilnya menunjukkan bahwa dalam jangka panjang maupun jangka pendek nilai tukar memiliki pengaruh yang negatip dan PDB dunia memiliki pengaruh yang positip terhadap volume ekspor Indonesia
\end{abstract}

Kata kunci: Volume Ekspor Indonesia, Nilai Tukar/KURS, Produk Domestik Bruto Dunia, Error Correction Mechanism (ECM)

\section{PENDAHULUAN}

Perdagangan antar negara lebih dikenal dengan istilah perdagangan internasional. Perdagangan internasional ini timbul karena adanya komoditas yang sama sekali tidak dapat diproduksi suatu negara akibat keterbatasan sumberdaya, keadaan alam, maupun iklim dan dianggap sebagai suatu akibat dari adanya interaksi antara permintaan dan penawaran yang bersaing. (Mutia, 2015)

Perdagangan internasional merupakan bentuk kerja sama ekonomi antar dua negara atau lebih yang memberikan manfaat secara langsung. Bentuk kerja sama antar negara ini dapat berupa kegiatan ekspor ataupun impor. Negara-negara yang melakukan kerja sama ekonomi, secara langsung akan meningkatkan penggunaan barang dan jasa (Putri \& Sulasmiyati, 2016). Ada dua kategori dalam perdagangan internasional, yaitu perdagangan barang dan perdagangan jasa. Kegiatan perdagangan internasional dilakukan bertujuan untuk meningkatkan standar hidup negara tersebut. Berdasarkan teori ekonomi, perdagangan (ekspor dan impor) merupakan salah satu kunci dari pertumbuhan ekonomi suatu negara, disamping konsumsi, 
investasi, dan pengeluaran pemerintah. Secara historis, pertumbuhan ekonomi di negaranegara maju sangat didukung oleh pertumbuhan ekspor sehingga negara-negara tersebut menguasai pangsa ekspor dunia. Dengan menggunakan Produk Domestik Bruto (PDB) sebagai indikator, perekonomin Indonesia berkembang sangat dinamis. Pada pemerintahan Era Orde Baru, pertumbuhan ekonomi tumbuh stabil pada kisaran 6\% - 7\% per tahun. Pada masa krisis khususnya pada periode 1998, ekonomi Indonesia justru mengalami kontraksi dengan laju pertumbuhan $-13,12 \%$. Setelah periode tersebut, ekonomi Indonesia mulai bangkit dengan laju pertumbuhan berkisar antara 5\% - 6\% per tahun (Lubis, 2017)

Perekonomian suatu negara juga dipengaruhi oleh nilai tukar/kurs mata uang dalam negri terhadap mata uang asing. Korelasi antara Nilai tukar dengan volume Perdagangan internasional menggunakan Model Mundell Fleming, mengasumsikan bahwa tingkat harga tetap dan menunjukkan penyebab fluktuasi jangka pendek dalam perekonomian terbuka kecil dengan mobilitas modal sempurna. Model Mundell Fleming menunjukkan bahwa depresiasi atau apresiasi nilai mata uang akan mengakibatkan perubahan terhadap ekspor maupun impor. Jika kurs mengalami depresiasi, yaitu nilai mata uang dalam negeri secara relatif terhadap mata uang asing menurun, volume ekspor akan menaik. (Mankiw, 2009)

Penelitian yang berkaitan dengan nilai tukar, produk domestik bruto, terhadap volume ekspor di indonesia sudah mulai banyak dilakukan. Mahendra dan Kesumajaya (2015) melakukan penelitian mengenai kurs dollar Amerika Serikat terhadap ekspor di Indonesia, hasil yang didapat yaitu Kurs dollar Amerika Serikat berpengaruh positif signifikan terhadap ekspor Indonesia tahun 1992-2012. Hasil yang berbeda di dapat dari hasil penelitian Ansharia, Khillab, dan Permatac (2017) Hasil penelitian menyimpulan Secara parsial, Variabel Kurs berpengaruh secara negatif terhadap ekspor di negara Indonesia, Malaysia, dan Singapura. Variabel kurs berpengaruh secara positif terhadap ekspor di negara Filipina dan tidak berpengaruh secara signifikan di negara Thailand.

Volume ekspor tidak hanya di pengaruhi nilai tukar (Kurs) namun juga dipegaruhi produk domestik bruto. Risma, Zulham, dan Dawood (2019) meneliti bagaimana PDB dan Nilai Tukar berpengaruh terhadap ekspor di Indonesia, hasil penelitian yang didapat adalah PDB berpengaruh secara positif dan signifikan terhadap ekspor. Nilai tukar berpengaruh secara negatif dan signifikan terhadap ekspor. Hasil yang berbeda didapat oleh Hidayat, Musadieq, dan Darmawan (2017) hasil penelitian menyatakan terdapat pengaruh negatif yang signifikan dari Nilai Tukar Rupiah terhadap US Dollar terhadap Nilai Ekspor Non Migas Indonesia. Terdapat pengaruh positif yang signifikan dari Nilai GDP Indonesia terhadap Nilai 
Ekspor Non Migas Indonesia. Hasil penelitian Lumadya Adi menyimpulkan bahwa hubungan jangka panjang Gross Domestic Product dengan ekspor tidak konsisten dengan teori karena adanya perubahan tanda semula positif berubah menjadi negatif.(Adi, 2017)

Berdasarkan uraian tersebut peneliti berusaha untuk menganalisis bagaimana keterkaitan antara nilai tukar, Produk Domestik Bruto dunia terhadap ekspor Indonesia.

\section{KERANGKA TEORI}

\section{Ekspor}

Ekspor adalah kegiatan mengeluarkan barang dari daerah pabean (Republik Indonesia, 2006).

Derah Pabean adalah wilayah Republik Indonesia yang meliputi wilayah darat, perairan dan ruang udara di atasnya, serta tempat-tempat tertentu di Zona Ekonomi Eksklusif dan landas kontinental. Ekspor merupakan barang dan jasa yang diproduksi di dalam negeri dan dijual secara bebas di luar negeri. Ekspor pada suatu negara dapat dipengaruhi oleh beragam faktor, baik itu merupakan faktor dari dalam negeri maupun luar negeri. Ekspor dapat dipengaruhi oleh beberapa faktor, yaitu: kemampuan suatu negara dalam memproduksi barang diekspor, dalam hal ini adalah mutu dan harga barang diekspor, cita rasa penduduk luar negeri, nilai tukar, pendapatan masyarakat, biaya transportasi barang, dan kebijakan pemerintah terkait dengan perdagangan internasional.(Mankiw, 2009)

2. Kurs

Kurs atau nilai tukar adalah perbandingan nilai antar mata uang atau harga suatu mata uang.

Nilai tukar atau kurs antara dua negara adalah tingkat harga yang disepakati penduduk kedua negara untuk saling melakukan perdagangan. Nilai tukar dapat berpengaruh positif dan negatif terhadap ekspor. Pengaruh positif terjadi ketika penguatan nilai tukar dapat mempengaruhi ekspor sehingga ekspor dapat bertambah. ketika harga suatu barang naik maka jumlah barang yang diminta akan turun dan ketika harga turun, maka jumlah barang yang diminta akan naik. Pengaruh negatif dari nilai tukar terjadi ketika nilai tukar mengalami pelemahan, maka ekspor naik atau bertambah. Nilai tukar dapat mempengaruhi harga suatu barang yang diekspor, sehingga ketika nilai tukar rupiah terhadap dollar menguat, maka harga barang ekspor akan naik.(Mankiw, 2009)

3. Produk Domestik Bruto 
Produk Domestik Bruto (PDB) merupakan jumlah barang dan jasa yang dihasilkan oleh seluruh penduduk yang berada di wilayah hukum suatu negara, tanpa memperhatikan apakah penduduk tersebut warga negara dari negara yang bersangkutan ataupun bukan. Produk domestik bruto dapat dihitung menggunakan dua harga yang ditetapkan oleh pasar. Pertama adalah dengan harga berlaku yaitu total nilai barang dan jasa yang diproduksi pada suatu negara dalam kurun waktu tertentu menggunakan harga yang berlaku pada periode tersebut. Kedua adalah dengan harga konstan yaitu total nilai barang dan jasa yang diproduksi oleh suatu negara dalam kurun waktu tertentu dengan menggunakan harga yang mengacu kepada harga tahun tertentu sebagai dasar perhitungan. Produk domestik bruto harga konstan sudah memasukkan unsur inflasi sehingga hasil yang didapat merupakan hasil riil suatu pendapatan perekonomian negara. (Risma, Zulham, \& Dawood, 2019)

\section{PENGEMBANGAN HIPOTESIS}

Depresiasi (jatuh) dalam nilai tukar riil domestik berarti bahwa barang-barang domestik telah menjadi relatif lebih murah dibandingkan dengan barang-barang asing. Perubahan ini mendorong konsumen di dalam dan luar negeri untuk membeli lebih banyak barang dalam negeri dan lebih sedikit barang dari negara lain. Akibatnya, ekspor domestik naik, dan impor turun; kedua perubahan ini meningkatkan ekspor neto domestik, dan sebaliknya.(Mankiw, 2009)

Efek dari nilai tukar riil pada ekspor suatu negara juga dapat dijelaskan dengan menggunakan model Mundell-Fleming. Nilai tukar riil yang dinyatakan dalam istilah langsung memiliki efek positif pada ekspor. Nilai tukar riil yang meningkat menunjukkan depresiasi mata uang Rupiah terhadap USD. Dengan demikian, IDR/USD riil yang tinggi berarti bahwa harga barang/jasa di Indonesia lebih murah sehingga akan meningkatkan ekspor.(Ginting, 2013)

Meningkatnya nilai Real Effective Exchange Rate (REER) menunjukkan bahwa Rupiah telah terdepresiasi, yang berarti bahwa harga barang/jasa Indonesia lebih murah untuk negara-negara lain di dunia, sehingga menyebabkan ekspor Indonesia meningkat. Dengan demikian, hipotesis pertama yang kami kembangkan dalam penelitian ini adalah

\section{H1: Nilai tukar riil (Kurs) memiliki efek positif pada volume ekspor Indonesia.}

Hukum permintaan dalam ekonomi mikro menyatakan bahwa ketika harga suatu barang naik, jumlah barang yang diminta akan berkurang, termasuk pāribus. Cēterīs pāribus 
berarti bahwa faktor-faktor lain yang mempengaruhi jumlah barang yang diminta dianggap konstan, tidak berubah, sehingga para ekonom akan lebih mudah menganalisis permintaan barang. Faktor lain yang mungkin mempengaruhi jumlah barang yang diminta adalah pendapatan konsumen. Peningkatan pendapatan konsumen, ketika harga barang ditetapkan, akan menyebabkan peningkatan jumlah barang yang diminta. Seorang konsumen yang memiliki lebih banyak pendapatan akan lebih fleksibel dalam membelanjakan uang mereka sehingga kemampuan mereka untuk membeli barang juga meningkat.

Dari perspektif perdagangan internasional, ekspor dari negara domestik juga disebut impor oleh negara mitra. Seperti hukum permintaan, jumlah ekspor suatu negara akan tergantung pada pendapatan konsumennya, yaitu pendapatan orang-orang di negara tujuan (Mankiw, 2009). Ketika pendapatan konsumen meningkat, kemampuan mereka untuk membeli barang juga akan meningkat. sehingga meningkatkan jumlah ekspor.

Penelitian ini menggunakan Produk Domestik Bruto dunia (PDB) per kapita sebagai proksi untuk mengukur pendapatan riil dunia. Variabel ini diwakili oleh PDB per kapita dunia dalam dolar AS 2010 yang konstan.

PDB per kapita riil dunia variabel menunjukkan pendapatan konsumen di seluruh dunia. Nilai yang tinggi dari variabel ini menunjukkan tingginya kemampuan konsumen dunia untuk membeli barang/jasa sehingga diharapkan dapat meningkatkan volume ekspor Indonesia ke pasar dunia. Hipotesis kedua dari penelitian ini adalah, oleh karena itu,

H2: Pendapatan riil konsumen (PDBW) memiliki efek positif pada volume ekspor Indonesia.

\section{METODOLOGI PENELITIAN}

\section{Sumber Data}

Jenis data yang digunakan adalah data sekunder yaitu data volume ekspor, kurs, dan PDB Dunia yang diakses di https://data.worldbank.org dan data Badan Pusat Statistik Indonesia tahun 2019. Periode pengamatan adalah tahun 1976 sampai dengan 2018

\section{Metode Analisis}

Instrumen penelitian terdiri dari pengujian asumsi klasik yang setidaknya terdiri dari uji normalitas, heterodiksitas, autokorelasi dan multikoloniaritas sehingga diharapkan hasil regresi akan bebas dari bias.

Uji normalitas bertujuan untuk mengetahui apakah data telah terdistribusi secara normal yang berarti bahwa sampel yang digunakan dalam penelitian ini mampu 
menggambarkan populasi keseluruhan. Uji normalitas dapat dilakukan dengan menggunakan P-P plot dan Kolmogorov Smirnov. Data terdistribusi secara normal jika titik sebaran data terdistribusi disekitar garis diagonal.

Uji Multikoloneritas bertujuan untuk mengetahui adanya korelasi antara variabel independen. Untuk mengetahui ada tidaknya multikoloniaritas, setiap variabel harus memiliki nilai VIF dibawah 10 dan tolerance diatas 0,10. Uji heterodiksitas berfungsi untuk mengetahui apakah residual heterogen atau tidak.

Uji Autokorelasi berfungsi untuk mengetahui apakah sebuah data dipengaruhi oleh data itu sediri dalam periode sebelumnya dan hal ini biasanya terdapat dalam data time series. Untuk melakukan uji autokorelasi digunakan uji Durbin Watson Test dan digunakan metode Cochrane Orcutt untuk mengatasi isu autokorelasi jika ditemukan.

Sifat data dalam penelitian ini dalam bentuk data time-series membuat estimasi regresi palsu jika menggunakan Ordinary Least Square (OLS). Regresi palsu terjadi ketika koefisien determinasi cukup tinggi tetapi hubungan antara variabel independen dan dependen tidak memiliki arti. Ini terjadi karena hubungan antara keduanya hanya menunjukkan tren waktu.

Solusi untuk masalah ini adalah dengan menggunakan Error Correction Mechanism (ECM). (Gujarati \& Porter, 2009). Untuk variabel ini, peneliti menggunakan ECM untuk menguji hipotesis. Berikut adalah model yang di usulkan.

$\mathrm{EKSPOR}_{\mathrm{t}}=\mathrm{f}\left(\mathrm{KURS}_{\mathrm{t}}, \mathrm{PDBW}_{\mathrm{t}}\right)$

EKSPORt $=C+\beta 1$ KURSt $+\beta 2$ PDBWt + et

dengan arah pengaruh yang diharapkan dari turunan pertama masing-masing variabel:

$\frac{\partial E K S P O R_{\mathrm{t}}}{\partial K U R S_{\mathrm{t}}}>0$ and $\frac{\partial E K S P O R_{\mathrm{t}}}{\partial \mathrm{PDBW}_{\mathrm{t}}}>0$

EKSPOR $_{\mathrm{t}}$ menunjukkan volume ekspor Indonesia pada periode $\mathrm{t}, \mathrm{KURS}_{\mathrm{t}}$ adalah nilai tukar riil dalam bentuk rasio mata uang Indonesia per USD pada periode $t$, dan PDBW $_{t}$ adalah pendapatan riil konsumen yang diproksikan dengan PDB dunia per kapita pada periode t. Dua variabel terakhir diukur dengan harga konstan 2010 USD.

Data yang digunakan dalam penelitian ini adalah data sekunder. Data diperoleh dari berbagai sumber. Volume ekspor Indonesia diperoleh dari Badan Pusat Statistik Indonesia dalam ribuan ton. Nilai tukar riil variabel dinyatakan dalam satuan unit mata uang Indonesia 
(IDR) per mata uang AS (USD). Variabel ini diukur menggunakan nilai konstan 2010 dengan rumus berikut (Ginting, 2013):

$$
\mathrm{RER}=\mathrm{ER} \times \frac{\mathrm{FP}}{\mathrm{DP}}
$$

RER menunjukkan nilai tukar riil, sedangkan ER menunjukkan nilai tukar nominal dalam istilah langsung (IDR/USD), FP menunjukkan harga asing, dan DP menunjukkan harga variabel (Ginting, 2013). Penelitian ini menggunakan indeks harga konsumen di Indonesia sebagai proksi untuk harga variable dan indeks harga konsumen di AS sebagai proksi untuk harga asing (Xu, 2018).

Pendapatan riil konsumen diproksikan dengan PDB per kapita dunia yang diukur pada harga konstan 2010 dalam dolar AS. Data ini diperoleh dari Bank Dunia. Nilai semua variabel diukur dalam logaritma natural sehingga koefisien regresi yang diperoleh mencerminkan elastisitas variabel yang dipertanyakan.

\section{HASIL DAN PEMBAHASAN}

\section{Uji Asumsi Ordinary Least Square (OLS)}

1. Uji normalitas: data normal, Probability test $>\alpha=5 \%(0,475>0,05)$.

2. Uji Autokorelasi: tidak terjadi autokorelasi, Prob. Chi-Square $>\alpha=5 \%(0,0716>$ $0,05)$

3. Uji heterokedastisitas: tidak terjadi heterokedastisitas, Prob. Chi-Square $>\alpha=5 \%$ $(1,1844>0,05)$

4. Uji multikolinieritas: tidak terjadi multikolinieritas, niali VIF kurang dari 10. Nilai VIF (C: 2,491449, KURS: 1,066398, PDBW: 2,456764)

\section{Uji Stasioneritas Data}

1. Ekspor.

a. Syarat bahwa data asli tidak stasioner terpenuhi. Nilai probability test $>\alpha=$ $5 \%,(0,9643>0,05)$

b. Syarat bahwa data turunan level pertama stasioner terpenuhi. Nilai probability test $<\alpha=5 \%,(0,000<0,05)$

2. Kurs

a. Syarat bahwa data asli tidak stasioner terpenuhi. Nilai probability test $>\alpha=$ $5 \%,(1,1587>0,05)$ 
b. Syarat bahwa data turunan level pertama stasioner terpenuhi. Nilai probability test $<\alpha=5 \%,(0,000<0,05)$

3. PDBW:

a. Syarat bahwa data asli tidak stasioner terpenuhi. Nilai probability test $>\alpha=$ $5 \%,(0,991>0,05)$

b. Syarat bahwa data turunan level pertama stasioner terpenuhi. Nilai probability test $<\alpha=5 \%,(0,001<0,05)$

Uji Hipotesis

Tabel 1. Persamaan Jangka Panjang

Dependent Variable: LOG(EKSPOR)

Method: Least Squares

\begin{tabular}{lrlll}
\hline \hline \multicolumn{1}{c}{ Variable } & Coefficient & Std. Error & t-Statistic & Prob. \\
\hline \hline \multicolumn{1}{c}{ C } & -17.27542 & 1.436732 & -12.02411 & 0.0000 \\
LOG(KURS) & -0.154629 & 0.093976 & -1.645403 & 0.1077 \\
LOG(PDBW) & 3.444643 & 0.213699 & 16.11913 & 0.0000 \\
\hline \hline R-squared & 0.920687 & Mean dependent var & 12.27750 \\
Adjusted R-squared & 0.916721 & S.D. dependent var & 0.655127 \\
S.E. of regression & 0.189057 & Akaike info criterion & -0.426321 \\
Sum squared resid & 1.429704 & Schwarz criterion & -0.303447 \\
Log likelihood & 12.16590 & Hannan-Quinn criter. & -0.381009 \\
F-statistic & 232.1646 & Durbin-Watson stat & 0.534101 \\
Prob(F-statistic) & 0.000000 & & \\
\hline \hline
\end{tabular}

\section{Tabel 2. Uji Kointegrasi}

Null Hypothesis: ECT has a unit root

Exogenous: Constant

Lag Length: 3 (Automatic - based on AIC, maxlag=9)

\begin{tabular}{llcl}
\hline \hline & t-Statistic & Prob. $^{*}$ \\
\hline \hline Augmented Dickey-Fuller test statistic & -4.124477 & 0.0025 \\
\hline Test critical values: & 1\% level & -3.610453 & \\
& 5\% level & -2.938987 & \\
& 10\% level & -2.607932 & \\
\hline \hline
\end{tabular}

*MacKinnon (1996) one-sided p-values.

1. Persamaan jangka panjang, hasil pengujian EKSPORt $=\mathrm{C}+\beta 1 \mathrm{KURSt}+\beta 2 \mathrm{PDBWt}$ + et, EKSPORt $=-17.27542-0.154629 \mathrm{LOG}(\mathrm{KURS})+3.444643 \mathrm{LOG}(\mathrm{PDBW})$ 
a. Dalam jangka panjang nilai tukar riil/Kurs memiliki efek negatif terhadap volume ekspor, dengan nilai koefisien sebesar - 0,1546

b. Pendapatan riil konsumen/PDBW memiliki efek positif terhadap volume ekspor, dengan nilai koefisien sebesar 3,444643 bahwa kenaikan 1 persen pada PDBW memiliki sumbangan terhadap volume ekspor sebesar 3,44 persen

c. Kedua variabel tersebut memiliki pengaruh yang besar yang ditunjukkan dengan nilai ajusted $\mathrm{R}$ square sebesar 91,67 persen

\section{Tabel 3. Keseimbangan Jangka Pendek}

$0>\operatorname{ECT}(-1)>-1$

Dependent Variable: D(LOG(EKSPOR))

Method: Least Squares

Date: 12/23/19 Time: 11:41

Sample (adjusted): 19772018

Included observations: 42 after adjustments

\begin{tabular}{lrlrr}
\hline \hline \multicolumn{1}{c}{ Variable } & Coefficient & Std. Error & t-Statistic & Prob. \\
\hline \hline \multicolumn{1}{c}{ C } & 0.046821 & 0.029488 & 1.587827 & 0.1206 \\
D(LOG(KURS)) & -0.013750 & 0.114807 & -0.119770 & 0.9053 \\
D(LOG(PDBW)) & 0.095455 & 1.463758 & 0.065212 & 0.9483 \\
$\quad$ ECT(-1) & -0.254697 & 0.103988 & -2.449282 & 0.0190 \\
\hline \hline R-squared & 0.143898 & Mean dependent var & 0.047528 \\
Adjusted R-squared & 0.076310 & S.D. dependent var & 0.125972 \\
S.E. of regression & 0.121070 & Akaike info criterion & -1.294499 \\
Sum squared resid & 0.557004 & Schwarz criterion & -1.129007 \\
Log likelihood & 31.18448 & Hannan-Quinn criter. & -1.233840 \\
F-statistic & 2.129069 & Durbin-Watson stat & 1.489200 \\
Prob(F-statistic) & 0.112601 & & \\
\hline \hline
\end{tabular}

2. Persamaan jangka pendek $\mathrm{D}($ EKSPORt $)=\mathrm{C}+\beta 1 \mathrm{D}($ KURSt $)+\beta 2 \mathrm{D}($ PDBWt $)+\beta 3$ $\mathrm{ECT}(-1) \quad+$ et, $\quad \mathrm{D}(\mathrm{EKSPORt})=0.046821-0.013750 \mathrm{D}(\mathrm{LOG}(\mathrm{KURS})+$ 0.095455 D(LOG(PDBW)-0,2549ECT(-1)

a. Dalam jangka panjang nilai tukar riil/Kurs memiliki efek negatif terhadap volume ekspor, dengan nilai koefisien sebesar - 0,01375

b. Dalam jangka pendek variabel memiliki pengaruh signifikan apabila nilai $0>\operatorname{ECT}(-1)>-1$, dan nilai probability test $<\alpha=5 \%$, 
c. Dalam jangka pendek nilai tukar riil/kurs dan pendapatan riil konsumen/ PDBW memiliki pengaruh signifikan terhadap volume ekspor, yang ditunjukkan dengan nilai Error Corection Term (ECT) sebesar-0,2549

d. Nilai propability test sebesar $0,0190<0,05$, yang berarti ada pengaruh yang signifikan

\section{KESIMPULAN}

Berdasarkan hasil analisis dengan mekanisme koreksi kesalahan/Error Correction Mechanism (ECM) dalam jangka panjang maupun jangka pendek nilai tukar riil (KURS) memiliki pengaruh yang negatif terhadap Ekspor Indonesia. Hal ini berarti menguatnya nilai tukar/KURS akan menurunkan ekspor Indonesia. H1: Nilai tukar riil (Kurs) memiliki efek positif pada volume ekspor Indonesia, tidak terbukti. Sedangkan Pendapatan riil konsumen (PDBW) dalam jangka panjang maupun jangka pendek memiliki pengaruh yang positif, dan signifikan terhadap Ekspor Indonesia hanya dalam jangka panjang. Hal ini menunjukkan semakin meningkatnya Pendapatan riil konsumen (PDBW) semakin meningkat kinerja ekspornya. H2: Pendapatan riil konsumen (PDBW) memiliki efek positif pada volume ekspor Indonesia, terbukti.

Dalam jangka pendek koefisien ECT menghasilkan nilai negatip $0>(-0,2546)>-1$, yang mengandung arti bahwa model tersebut signifikan dan membutuhkan nilai sebear 0,2546 untuk keseimbangan dalam jangka pendek/dalam 1 tahun.

\section{DAFTAR PUSTAKA}

Adi, L. (2017). Pengaruh Exchange Rate dan GDP Terhadap Ekspor dan Impor Indonesia. Develop, 1(1). https://doi.org/10.25139/dev.v1i1.69

Anshari, M. F., El Khilla, A., \& Rissa Permata, I. (2017). Analisis Pengaruh Inflasi dan Kurs terhadap Ekspor di Negara ASEAN 5 periode tahun 2012-2016. INFO ARTHA, 1(2), 121. https://doi.org/10.31092/jia.v1i2.130

Ginting, A. M. (2013). Pengaruh Nilai Tukar Terkadap Ekspor Indonesia. Buletin Ilmiah Litbang Perdagangan, 7(1), 1-17. https://doi.org/http://dx.doi.org/10.30908/bilp.v7i1.96

Gujarati, D., \& Porter, D. (2009). Basic Econometrics. (5th ed.). New York: McGraw-HiII.

Hidayat, N. F., Al Musadieq, M., \& Darmawan, A. (2017). PENGARUH FOREIGN DIRECT INVESTMENT, NILAI TUKAR DAN PERTUMBUHAN EKONOMI TERHADAP EKSPOR (Studi pada Nilai Ekspor Non Migas Indonesia Periode Tahun 2005-2015). Jurnal Administrasi Bisnis S1 Universitas Brawijaya, 43(1), 172-179.

Mahendra, I. G. Y \& Kesumajaya, I. W. W. (2012). Analisis pengaruh investasi, inflasi, kurs dollar Amerika serikat dan suku bunga kredit terhadap Ekspor Indonesia tahun 1992- 
2012. E-Jurnal EP Unud, 4(Mei 2015), 525-545.

Lubis, A. (2017). Kinerja ekspor batik indonesia.pdf. Buletin Ilmiah Litbang Perdagangan, Vol. 4 No. 1, Juli 2010.

Mankiw, G. (2009). Brief Principles of Macroeconomics. In South-Western Cengage Learning (6th ed.). South-Western: Cengage Learning.

Mutia, R. (2015). Analisis pengaruh Kurs, Pdb dan Tingkat Inflasi terhadap Ekspor Indonesia ke Negara Asean (Studi pada Negara Malaysia, Singapura, Filipina, dan Thailand). 1-83. Retrieved from http://eprints.undip.ac.id/45461/

Pratiwi, A. R., Murdiati, S., \& Herwinarni, Y. (2019). Pengaruh BI Rate, Inflasi, Nilai Tukar Rupiah, PDB Perkapita dan Jumlah Uang Beredar Terhadap Permintaan Reksa Dana Saham Tahun 2013 - 2017. Permana : Jurnal Perpajakan, Manajemen, Dan Akuntansi, 11(1), 1-10. https://doi.org/10.24905/permana.v11i1.21

Putri, Ra. F. A., \& Sulasmiyati, S. (2016). Pengaruh inflasi dan nilai tukar terhadap ekspor indonesia komoditi tekstil dan elektronika ke korea selatan. Jurnal Administrasi Bisnis S1 Universitas Brawijaya, 35(1), 127-136.

Republik Indonesia. Undang-undang Nomor 17 Tahun 2006 tentang Perubahan Atas Undang-undang Nomor 10 Tahun 1995 tentang Kepabeanan. , 33 Lembaran Negara RI tahun $2006 \S$ (2006).

Risma, O. R., Zulham, T., \& Dawood, T. C. (2019). Pengaruh Suku Bunga, Produk Domestik Brutio dan Nilai Tukar terhadap Ekspor di Indonesia. JURNAL PERSPEKTIF EKONOMI DARUSSALAM, 4(2), 300-317. https://doi.org/10.24815/jped.v4i2.13027

Riziqyani, A., Gunistiyo, \& C, N. W. (2018). Pengaruh Kurs, Suku Bunga, dan Dividen Pershare Terhadap Harga Saham Pada Sektor Perbankan yang Terdaftar di Bursa Efek Indonesia Tahun 2013- 2017. Permana : Jurnal Perpajakan, Manajemen, Dan Akuntansi, 10(1), 21-33. https://doi.org/10.24905/permana.v10i1.62

$\mathrm{Xu}$, Z. (2018). China's exports, export tax rebates and exchange rate policy. The World Economy, 41(5), 1288-1308. https://doi.org/10.1111/twec.12570 